\begin{tabular}{|c|c|c|c|c|c|c|}
\hline \multirow{4}{*}{ Impact Factor: } & ISRA (India) & $=3.117$ & SIS (USA) & $=0.912$ & ICV (Poland) & $=6.630$ \\
\hline & ISI (Dubai, UAE & $=0.829$ & РИНЦ (Russia & $=0.156$ & PIF (India) & $=1.940$ \\
\hline & GIF (Australia) & $=0.564$ & ESJI (KZ) & $=8.716$ & IBI (India) & $=4.260$ \\
\hline & JIF & $=1.500$ & SJIF (Morocco & $=5.667$ & OAJI (USA) & $=0.350$ \\
\hline
\end{tabular}

\section{SOI: $1.1 /$ TAS DOI: $10.15863 /$ TAS International Scientific Journal Theoretical \& Applied Science}

\author{
p-ISSN: 2308-4944 (print) e-ISSN: 2409-0085 (online) \\ Year: 2019 Issue: $05 \quad$ Volume: 73
}

Published: $21.05 .2019 \quad \underline{\text { http://T-Science.org }}$
QR - Issue

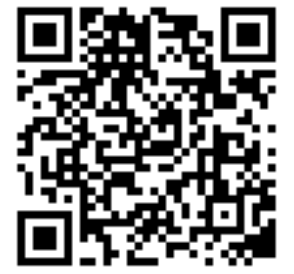

QR - Article

Mexriniso Azamatovna Yarmatova

Senior lecturer, Russian language teacher; Mexriniso_Y@mail.ru

Shoxida Egamberdievna Turaeva

Senior lecturer, Russian language teacher; Department of Uzbek and Russian languages

Karshi Engineering-Economic institute

\title{
TEXT ANALYSIS IN GEODESY AND MAPPING ENGINEERING CONTEXTS
}

\begin{abstract}
In teaching Russian language, corpus-linguistics plays crucial role in text analysis; collocations, concordances, types and tokens, frequency-words occurring in target language. Even single word gives a written context changes or other meaning. In this study, we conducted a research on the issues of constructing words such as; single words, collocations, and frequency-words occur in Russian language context. In the classes of Russian language for specific purposes, we focused on technical context of the geodesy and mapping field to analyze because there are some tokens and types which students of engineering need to acquire in order to use them in spoken context. However, we may see strong tokenization in the context of geodesy and mapping engineering. This paper highlights discussions of scholars on the issues of corpus linguistics, especially, analysis of collocations, tokens and types occurring in written context.

Key words: collocations, frequency words, written context.

Language: English

Citation: Yarmatova, M. A., \& Turaeva, S. E. (2019). Text Analysis in Geodesy and Mapping Engineering Contexts. ISJ Theoretical \& Applied Science, 05 (73), 123-125.

Soi: http://s-o-i.org/1.1/TAS-05-73-20 Doi: crossef https://dx.doi.org/10.15863/TAS.2019.05.73.20
\end{abstract}

\section{Introduction}

The growth of corpus linguistics (5) has convinced linguists that vocabulary is much more than the 'unordered list of all lexical formatives' which Chomsky (2:84) referred to it. Corpora reveal that much of our lexical output consists of multi-word units; language occurs in ready-made chunks to a far greater extent than could ever be accommodated by a theory of language insistent upon the primacy of syntax. Recent developments in the study of lexis have generated new applications within lexicography and language teaching, offering the possibility of a better understanding of the nature of the lexicon, especially multi-word phenomena. Besides, the notion of collocation shifts the emphasis from the single word to pairs of words as integrated chunks of meaning in the contexts, and collocation has become an uncontroversial element in a good deal of language description and pedagogy. Firth famously proposed that the meaning of a word was as much a matter of how the word combined in context with other words (i.e., its collocations) as any inherent properties of meaning it possessed of itself: dark is part of the meaning of night, and vice-versa, through their high probability of co-occurrence in texts (6). Collocation studies show, most importantly, that a good deal of semantically transparent vocabulary is to a greater or lesser degree fossilized into restricted patterns (1). Moreover, there are some tokens and types, frequent words occurring in the context of specialty, which is more needed to acquire and use in target environment. Present study shows text analysis, indicating of discussion; collocations, corpora, and tokens and types occurring geodesy and mapping engineering in Russian language.

\section{Single Word}

In the study of the lexicon, the single word has remained, until recently, relatively unchallenged as the basic unit of meaning and as the focus in the study of lexical acquisition in second and foreign languages. This is not without good reason: single words form a substantial part of the lexicon of Russian language and are perceived in pedagogy as the central units to be 


\begin{tabular}{|c|c|c|c|c|c|c|}
\hline \multirow{4}{*}{ Impact Factor: } & ISRA (India) & $=3.117$ & SIS (USA) & $=0.912$ & ICV (Poland) & $=6.630$ \\
\hline & ISI (Dubai, UAI & $=0.829$ & РИНЦ (Russia & $=0.156$ & PIF (India) & $=1.940$ \\
\hline & GIF (Australia) & $=0.564$ & ESJI (KZ) & $=8.716$ & IBI (India) & $=4.260$ \\
\hline & JIF & $=1.500$ & SJIF (Morocce & $=5.667$ & OAJI (USA) & $=0.350$ \\
\hline
\end{tabular}

acquired. Other units consisting of more than one word, such as phrasal verbs, compounds and idioms are often thought of as items belonging to higher levels of achievement. There are, of course, exceptions to this: greetings and other phatic expressions (e.g., Как твоя дела? До скорой встречи, большое спасибо), specialized functional phrases (e.g., С днем рождения, удачи), basic prepositional phrases (е.g., утром, дома), and common compounds (e.g., автостоянка, регистрация ) are often taught and/or acquired even at elementary level.

\section{Collocation in Russian language context}

Recent developments in the study of lexis have generated new applications within lexicography and language teaching, offering the possibility of a better understanding of the nature of the lexicon, especially multi-word phenomena. The collocational dimension of the mental lexicon has been increasingly seen as playing a vital role in respect of both L1 acquisition and L2 acquisition (3). Proponents of formula-based approaches to language learning maintain that the learning of fixed formulas is an essential aspect of the language learning process, and that it leads to the development of creative aspects of language (10: 305 $307 ; 7: 114-116)$. According to this account, sequence learning lies at the very heart of language learning in that it involves "learning sequences of words (frequent collocations, phrases, and idioms)" and sequences within words (4: 45-46). Learning vocabulary involves sequencing at the level of syllable structures, while learning discourse involves sequencing of words, collocations and longer phrases within the frequency-based approach collocations are generally regarded as units made up of words that co-occur within a certain distance from one another with higher frequency than would be expected on the basis of coincidence or linguistic rules (3: 11).L1 users have normally accumulated a huge number of collocations and longer lexical chunks by the time L1 is a fully developed system. In the case of adult L2 learners, however, collocational knowledge tends to lags behind (9:1-24). While there is some evidence to suggest that adult language learners are relatively successful at producing simple conversational formulas at initial stages of L2 learning (8), at higher levels of L2 proficiency producing natural-sounding L2 output that abounds in native-like collocations appears to pose a somewhat larger challenge for L2 learners. We found that some frequency occurring words may exist in every Russian language context of geodesy and mapping because each context connect with each other by meaning.

\section{Frequency occurring words in Russian language context}

A word (or word-form) may be quite frequent, but majority, or even all, of its occurrences might be in just one or two texts, in which case, although its frequency might look significant, its range might be quite small. The useful words for the learner are those words which are frequent and have a fairly wide rage that is those which occur across a wide variety of texts. Information about range can be presented in the form of statistical comparison between the occurrence of a word in one part of a corpus (e.g. just the scientific texts in the corpus) and its occurrence in the corpus as a whole. Any word that gets a differential of around 16 occurs with more or less the same frequency in the scientific texts as in the whole corpus. Any word with a lower differential is not very characteristic of scientific and learned English. Words with high differentials are characteristic of scientific and learned language (5: 40). We may see frequent occurring words in the contexts of one specialty; geodesy and mapping engineering; Штатив геодезиста, фотоштативов, неподвижно зафиксировать, трегер, прибор-тахеометр, нивелир, вешка, лазерная рулетка, геодезических бригад, рулетка, трубо-кабелеискатель. These technical words often occur in the context of geodesy and mapping engineering as well as mining engineering in Russian language context, and they are considered as tokens and types.

\section{Tokens and types}

Lexical variation takes as its starting point the distinction between token and type. If a text is 50 words long, it is said to contain 50 tokens, but many of these tokens may be repeated within the text and this may give us a considerable lower total of types; she promised him she would write to him and write to him she did 'there are 14 tokens but some are repeated; there are only 8 types, (she', promised, him, would, write, to, and, did,). The ratio between tokens and types for this sentence is $14: 8$; the difference between the two numbers is great, indicating a fairly low load of differing items. In the sentence 'as the trees grow gold and brown, then autumn has come to replace summer', we have 14 tokens and 14 types, so the vocabulary load is quite high, with no repetition. Lexical variation counts do give us a rough measure of how many new items are introduced into a text as it unfolds; this may not be the same as new words for a language learner, but it can be a useful measure in predicting the likely degree of difficulty a text might present (5.42). In the context of geodesy and mapping engineering, tokens may occur more than types;

1).Штатив; очень простой инструмент геодезиста. Многие сталкивались с ним при съемках фотографий или фильмов в хорошем качестве. От фотоштативов геодезические отличаются в основном простотой конструкции и неприхотливостью в использовании.

2).Основная задача геодезического штативанеподвижно зафиксировать прибор, который на него ставится над определенной точкой/пунктом на земле. На штатив сначала ставится трегер- 


\begin{tabular}{|c|c|c|c|c|c|c|}
\hline \multirow{4}{*}{ Impact Factor: } & ISRA (India) & $=3.117$ & SIS (USA) & $=0.912$ & ICV (Poland) & $=6.630$ \\
\hline & ISI (Dubai, UAI & $=0.829$ & РИНЦ (Russia & $=0.156$ & PIF (India) & $=1.940$ \\
\hline & GIF (Australia) & $=0.564$ & ESJI (KZ) & $=8.716$ & IBI (India) & $=4.260$ \\
\hline & JIF & $=1.500$ & SJIF (Morocco & $=5.667$ & OAJI (USA) & $=0.350$ \\
\hline
\end{tabular}

специальное устройство для центрования над точкой и горизонтирования прибора. Потом уже ставится прибор-тахеометр, нивелир и т.д. Различают деревянные, металлические и штативы из композитных материалов.

According to the $1^{\text {st }}$ context, there are 30 tokens and 30 types in the corpus of the geodesy and mapping engineering, and we found frequency occurred words within corpus of the geodesy and mapping engineering, they are; Штатив this main instrument occurs also in other written contexts of this field.

According to the $2^{\text {nd }}$ context, there are 45 tokens and 40 types in the context of geodesy and mapping engineering, and we found that instrument "трегер" frequent word also occurred in other texts of this field of.

\section{Conclusion}

In the classes of Russian language for specific purposes, we focus on professionally-oriented context to teach and design the class, coloring it because there are some tokens and types which frequently occurs not only in one text but also does in other written contexts which tell us about the subject matter and those learners need to know. We study collocations which modify the words related to, and vocabulary words which are tokens and types. We analyzed technical text to find out whether how many times one word occur in other sentences within specialty, and how many tokens and types does it consist of. We addressed to the discussions of scholars on the issues of collocations, tokens and types, corpora. As a result, findings were shown in the above-mentioned text examples.

\section{References:}

1. Aisenstadt, E. (1981). Restricted collocations in English Lexicology and lexicography. ITL Review of Applied Linguistics 53: 53-61.

2. Chomsky, N. (1965). Aspects of the Theory of Syntax. Cambridge Mass: MIT Press

3. Durrant, P., \& Schmitt, N. (2009). "To what extent do native and non-native writers make use of collocations?" International Review of Applied Linguistis.

4. Ellis, N. (1996). "Sequencing in SLA: Phonological memory, chunking, and points of order". Studies in Second Language Acquisition 18: 91-126.

5. McCarthy, M. (1998). Spoken Language and Applied Linguistics. Cambridge: Cambridge University Press.
6. McCarthy, M. (2006). Explorations in Corpus Linguistics. Cambridge University Press. London.

7. Nattinger, J. R., \& DeCarrico, J. S. (1992). Lexical Phrases and Language Teaching. Oxford: Oxford University Press.

8. Pawley, A., \& Syder, F. H. (1983). "Two Puzzles for Linguistic Theory: Nativelike Selection and Nativelike Fluency." In J. C. Richards and R. W. Schmidt (Eds.). Language and Communication. London: Longman.

9. Shokouhi, H. (2010). "Collocational Knowledge Versus General LinguisticKnowledge among Iranian Efl Learners". The Electronic Journal for English as a Second Language 13 (4): 1-24.

10. Tomasello, M. (2003). Constructing a Language: A Usage-Based Theory of Language Acquisition. London: Harvard University Press. 